\title{
Development of materials based on PET-siliceous sand composite aggregates
}

\author{
Gouasmi M.T.1, ${ }^{*}$, Benosman A.S. ${ }^{1,2,3}$, Taïbi H. ${ }^{1}$
}

\author{
1 Faculty of Exact and Applied Sciences, Laboratory of Polymer Chemistry LCP, University of Oran 1, Ahmed \\ Benbella, BP 1524, El Mnaouer, Oran 31000, Algeria. \\ 2 Higher School of Applied Sciences, ESSA-Tlemcen, Bel Horizon, 13000 Tlemcen, Algeria. \\ 3 Department of Civil Engineering, Laboratory of LABMAT, ENPO Maurice Audin, Oran, Algeria. \\ * Corresponding Author: m.t.gouasmi@hotmail.fr
}

\begin{abstract}
Plastic waste recycling for the development of new building materials, such as cementitious composites, appears to be one of the best solutions to get rid of this type of waste. This operation has many economic and ecological advantages. The present study proposes some solutions for the recovery of plastic waste from PET (polyethylene terephthalate) bottles in order to obtain, after heat treatment at $290{ }^{\circ} \mathrm{C}$ followed by step cooling, a light composite material (PET-siliceous sand) with a hardness close to that of natural rock. The structure of the material obtained is characterized first; then the effect of this composite, with different substitution rates of natural aggregate, on the behavior of an industrial screed is studied. Afterwards, some specific recommendations for the uses of this screed, and possibly of the composite itself, are given. Although the main effects of certain polymeric additives on the mechanical properties of mortars are known, the mechanisms that are responsible for these effects are not yet well understood. Techniques such FTIR, XRD, SEM and differential scanning calorimetry (DSC) are analytical tools that can be used for the characterization and expertise of this type of composites, particularly the industrial composite screeds. Results from the present article enabled us to state that the composition of the materials obtained remains qualitatively unchanged and that no chemical interaction was observed between the mineral species and the waste PET lightweight aggregate (WPLA) or the composite itself; in fact, no new compounds were formed. In addition, the differential scanning calorimetry (DSC) technique allowed us to conclude that the addition of WPLA has an influence on cement hydration. The thermo-mechanical characterization of WPLA made it possible to observe an excellent arrangement between the PET and siliceous sand. Therefore, the development of WPLA may be another solution for a number of applications in the field of eco-materials for construction and building.
\end{abstract}

Key words: Green/eco composite; Recycled materials; PET polymer; WPLA (Waste PET Lightweight Aggregate); Microstructural analyses.

\section{Introduction}

In the field of construction, a screed is a mortar layer made of cement, resin or lime, applied on the ground and intended to flatten, level, come on a support and / or coat elements, such as a heating floor, and then to receive the upper layers, like tiles, a flexible floor, a floating or glued floor (Fiches Techniques G11, 2013). Depending on the design and method of execution, two different types of screeds may be mentioned, namely the adhering screeds, which are incorporated or attached, and the floating screeds. The use of polymer waste in building materials has been evolving for decades. Various kinds of screeds, composite mortars and concretes, plastic aggregates (Alfahdawi et al. 2016; Gu and Ozbakkaloglu, 2016) and composite aggregates WPLA (Akçaözoğlu et al. 2013; Choi et al. 2009; Zuccheratte et al. 2017) have been formulated so far. These new applications came to respond to specific demands expressed by building and civil engineering professionals, in particular for the acoustic and thermal comfort and durability. 
The aim of the present work is to present the results of a first experimental study on the characterization of the structure obtained using IRTF, XRD, SEM techniques as well as thermal analysis techniques, such as DSC, for building elements, like screeds made of composite aggregates (PET- siliceous sand), which contain crushed PET waste. These composite aggregates are used as substitutes for natural aggregates in order to make an industrial composite screed. This represents an important contribution to sustainable development. Some optimal substitution proportions have been studied as well in order to determine the feasibility limits, unlike what has been undertaken in previous works (Alqahtani et al. 2014, 2017; Choi et al. 2005, 2009; Zuccheratte et al. 2017). In general, the WPLA aggregate composites obtained seem to be inexpensive materials that could help solve some solid waste disposal problems, in addition to the energy gain they can generate.

\section{Experimental program}

\subsection{Cement}

The type of cement used is Matine 42.5 CPJ CEM II/A, from Lafarge Cement Plant, based in Oggaz (North-West of Algeria). This cement has a fineness of $4500 \mathrm{~cm}^{2} / \mathrm{g}$, absolute density of 3.09 $\mathrm{g} / \mathrm{cm}^{3}$ and average compressive strengths of $22 \mathrm{MPa}$ at 2 days, and $48 \mathrm{MPa}$ at 28 days. The chemical composition of cement, siliceous sand $\left(\mathrm{S}_{\mathrm{s}}\right)$ and calcareous sand $\left(\mathrm{C}_{\mathrm{s}}\right)$ as well as the mineralogical composition of clinker are given in Tables 1 and 2, respectively.

Table 1. Elementary chemical composition of $\mathrm{CPJ} 42.5$ cement, siliceous $\left(\mathrm{S}_{\mathrm{s}}\right)$ and calcareous $\left(\mathrm{C}_{s}\right)$ sands, wt. \%

\begin{tabular}{|c|c|c|c|}
\hline Oxides & Cement & $\mathrm{S}_{\mathrm{s}}$ & $\mathrm{C}_{\mathrm{s}}$ \\
\hline \hline $\mathrm{SiO}_{2}$ & 17.40 & 83.29 & 11.76 \\
\hline $\mathrm{Al}_{2} \mathrm{O}_{3}$ & 4.12 & 0.21 & - \\
\hline $\mathrm{Fe}_{2} \mathrm{O}_{3}$ & 2.97 & 0.45 & 0.91 \\
\hline $\mathrm{CaO}$ & 61.15 & 7.03 & 44.35 \\
\hline $\mathrm{MgO}$ & 1.16 & 4.2 & - \\
\hline $\mathrm{K}_{2} \mathrm{O}$ & 0.66 & - & - \\
\hline $\mathrm{SO}_{3}$ & 2.46 & - & - \\
\hline $\mathrm{Na}_{2} \mathrm{O}$ & 0.13 & - & - \\
\hline $\mathrm{LOI}^{2}$ & 8.85 & - & - \\
\hline $\mathrm{Cl}^{-}$ & 0.017 & - & - \\
\hline $\mathrm{CaCO}_{3}$ & - & 2.27 & 59.09 \\
\hline $\mathrm{CO}_{2}$ & - & 1.00 & 26 \\
\hline \multicolumn{4}{|c}{ LOI: loss on ignition. } \\
\hline
\end{tabular}

Table 2. Mineralogical composition of clinker (\%w)

\begin{tabular}{|c|c|c|c|}
\hline $\mathrm{C}_{3} \mathrm{~S}$ & $\mathrm{C}_{2} \mathrm{~S}$ & $\mathrm{C}_{3} \mathrm{~A}$ & $\mathrm{C}_{4} \mathrm{AF}$ \\
\hline \hline 64 & 15 & 8 & 12.16 \\
\hline
\end{tabular}

\subsection{Thermomechanical protocol for the preparation of the composite aggregate WPLA} (Waste PET Lightweight Aggregate)

It is a combination of a natural element, i.e. silica sand, and upgraded waste PET bottles. Heat treatment followed by a stepwise cooling is required in order to have slices with hardness close to that of natural rock (Figure 1a). These fragments undergo an industrial grinding, giving different granular fractions; the one used in this study is $0 / 0.3$ (Figure 1b). The chemical composition of silica sand used and the XRD analysis, MOP picture of WPLA microstructure are shown in Table 1 and Figures 1c.d, respectively. 


\subsection{Calcareous sand}

The calcareous sand (CS), which will be substituted by the composite aggregate WPLA throughout this study, is a calcium-silicate sand from SECH quarries of HASNAOUI Group, based at Sidi Ali Benyoub (Wilaya of Sidi Bel Abbes, Algeria). The chemical composition of the sand used, is shown in Table 1.

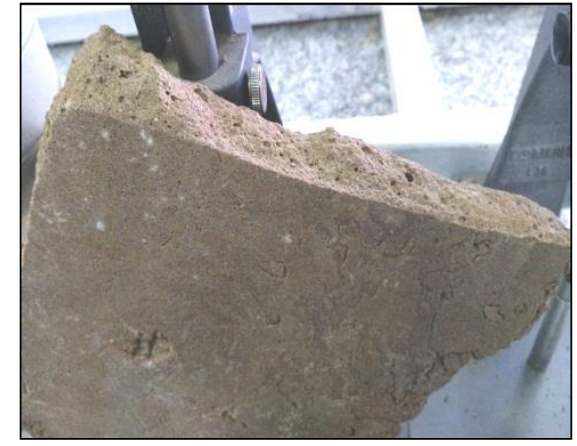

(a)

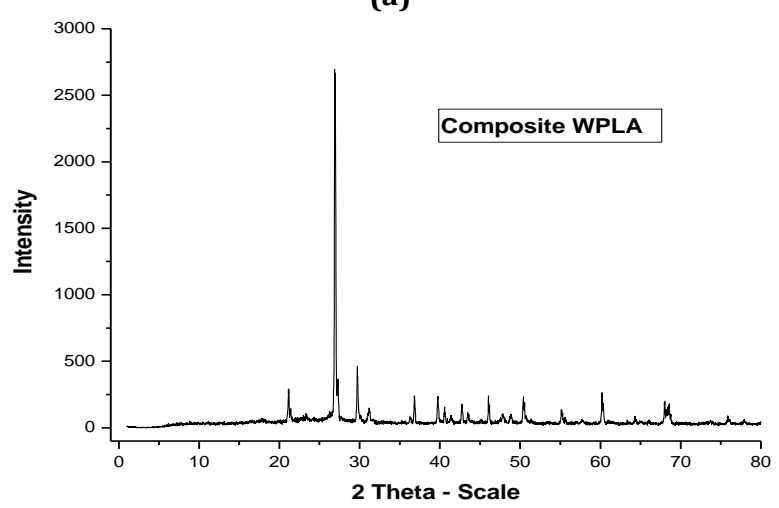

(c)

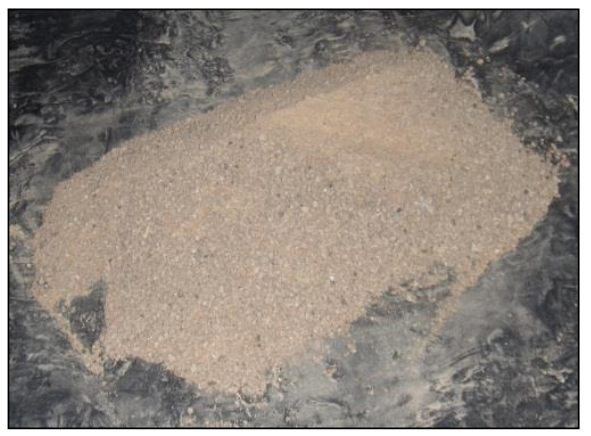

(b)

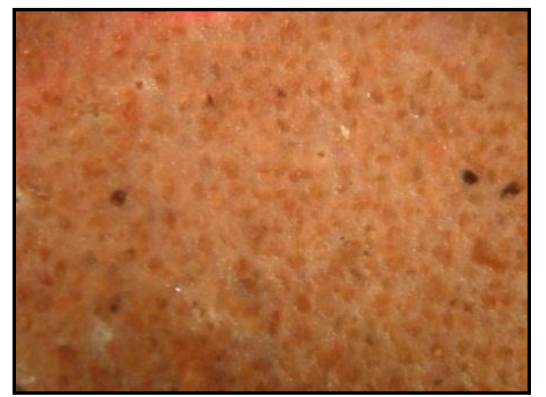

(d)

Fig 1. (a) Slices, (b) Granular fractions, (c) XRD spectrum and (d) Optical Microscope picture (4.8x) of the WPLA composite aggregate

\subsection{Test Methods}

It was Granular mixtures for the preparation of composite screed mortars were prepared from Matine cement, and four combinations were obtained by partial and total replacement of the starting silico-calcareous sand by $25 \%, 50 \%, 75 \%$ and $100 \%$ by weight of the WPLA composite aggregate previously prepared. For each formulation, the mixtures were prepared based on Standard ASTM C109-11 (2011), in order to fabricate specimens with dimensions $5 \times 5 \times 5 \mathrm{~cm}^{3}$. These mixtures were composed of one third of binder (cement) and two thirds of aggregates with respect to the overall weight. These aggregates are calcareous sand and WPLA. The water to cement (W/C) ratios used allowed for workability values between 85 and 105 . The maneuverability of each type of the formulated mortars was measured according to Standard ASTM C 1437 (2001), using the spreading table test. The molds containing the samples were covered with a plastic film and stored in the maturation cabinet of the laboratory. After 24 hours, the samples were unmolded and immersed in lime-saturated water (ASTM C511, 2006), for 28 days, at the temperature of $20 \pm 2^{\circ} \mathrm{C}$. The compression and flexural strengths of the samples were measured using a hydraulic press after 28 days (NFEN 196-1, 2005).

The characterization of the previous materials, conserved in water, was carried out using various analytical techniques, such as the Differential Scanning Calorimetry (DSC) Thermal Analysis which was carried out in the laboratory of CHIALI Group, located in the industrial zone of the town of Sidi Bel Abbes. The apparatus used is a differential scanning calorimetric analyzer (DSC, NETZSCH DSC 200PC, with temperature rise ramps equal to $10 \mathrm{~K} / \mathrm{min}$, up to $600{ }^{\circ} \mathrm{C}$, 
under nitrogen flux).Test samples of mortar, composite, siliceous sand and PET were analyzed according to linear heating, starting from ambient temperature up to $600{ }^{\circ} \mathrm{C}$, with a heating rate of $10 \mathrm{~K} / \mathrm{min}$. The analysis of the samples was carried out on an attenuated total reflection (ATR) patch, using a Spectrum One PerkinElmer FT-IR spectrometer. The FT-IR spectra were obtained by applying the FTIR-ATR infrared spectrometry technique to the samples for a few minutes. The SEM and XRD analyses were performed using a HITACHI TM-1000 apparatus and a Bruker D8 ADVANCE diffractometer $(\mathrm{Cu}-\mathrm{K} \alpha)$, respectively.

\section{Results and discussion}

\subsection{Interpretation of FTIR spectra of the composite aggregate and composite screed mortars}

The polymer PET is characterized by the presence of the following remarkable absorption bands (Figure 2a):

- $\quad$ around $867.3 \mathrm{~cm}^{-1}$ (out-of-plane or para-disubstituted alternating cycle deformations),

- near $1095.8 \mathrm{~cm}^{-1}$, due to the vibrations of the -CO- bond,

- at $1577.9 \mathrm{~cm}^{-1}$ and $1616.1 \mathrm{~cm}^{-1}$, due to the vibration modes of the benzene ring,

- $\quad$ around $1715.8 \mathrm{~cm}^{-1}$, due to the grouping -COO-,

- at $2858.0 \mathrm{~cm}^{-1}$ and $2924.0 \mathrm{~cm}^{-1}$, characteristic of the bonds $-\mathrm{CH}_{2-}^{-}$,

- Around $3002.2 \mathrm{~cm}^{-1}$, due to the valence vibrations $\mathrm{UCH}$ of the benzene ring (Figure 2a).

It is important to mention that the amount of the valorized polymer (PET) is much less than that of silica sand in the WPLA composite aggregate. This component (PET) is completely masked by the vibrations of the siliceous sand bonds. These vibrations are present in the spectrum of the WPLA composite (in Figure 2, presence of broad and intense absorption bands around $1200 \mathrm{~cm}^{-}$ $11600 \mathrm{~cm}^{-1}$, and especially around $910 \mathrm{~cm}^{-1}$, which is characteristic of the Si-O bond of silica, Figure $2 b)$.

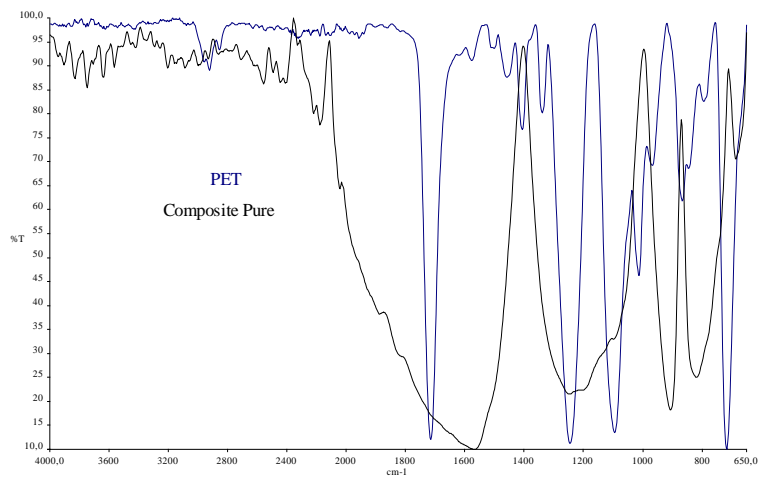

(a)

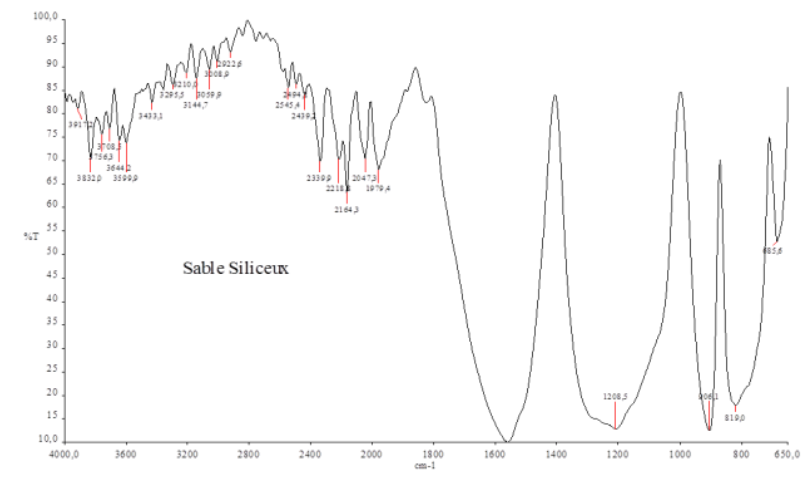

(b)

Fig 2. (a) Superposition of FTIR spectra of PET and composite aggregate, (b) FTIR spectra of siliceous sand.

Figures 3 and 4 display the superposition of FTIR spectra of samples of PET, composite aggregate, WPLA0 and WPLA100. The spectra are distinguished by the presence of specific lines for PET, composite aggregate and WPLA100. It is found that the characteristic lines of the Waste PET Lightweight Aggregate (WPLA) correspond exactly to those observed on the WPLA100. The lines characterizing the PET are masked by those of the WPLA composite, as shown in Figure 4. 


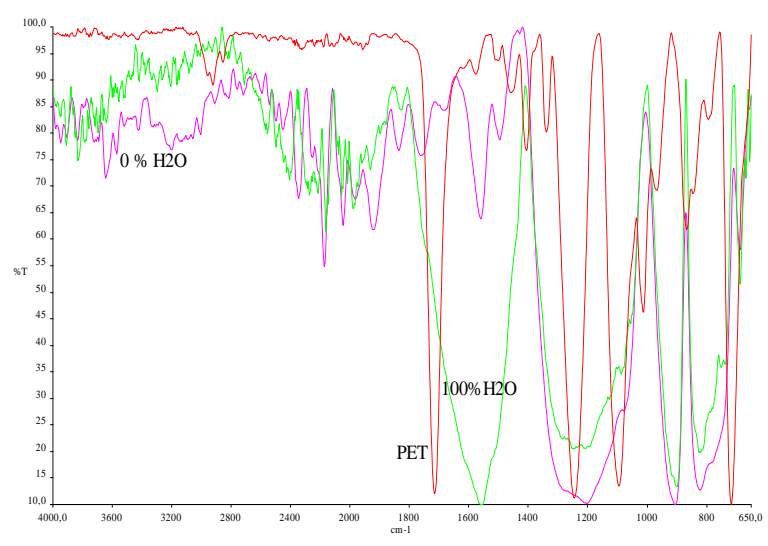

Fig 3. Superposition of the FTIR spectra of the samples WPLA0, WPLA100 and PET (Gouasmi et al. 2017).

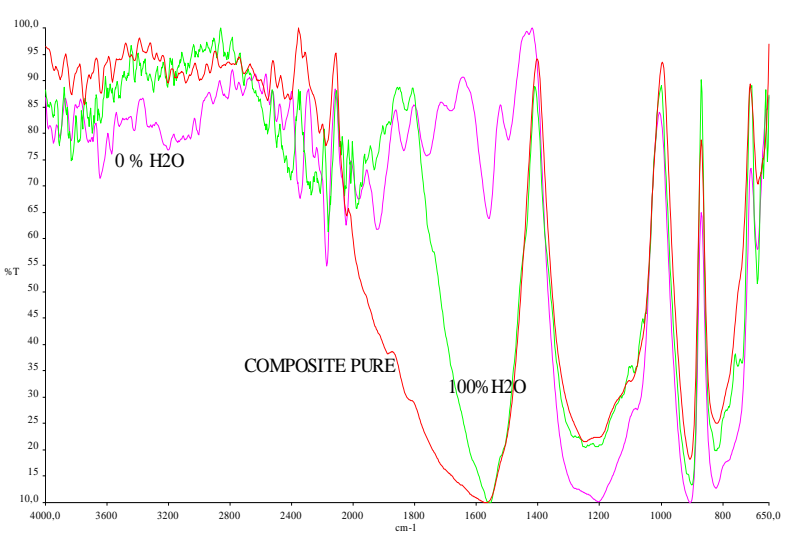

Fig 4. Superposition of the FTIR Spectra of the samples WPLA0, WPLA100 and composite aggregate.

All the spectra obtained for the composites showed the same lines, more or less intense, depending on the WPLA composite aggregate content, as shown in Figure 5. In view of the high number of results, it was necessary to reduce the number of spectra relating to samples WPLA50 and WPLA75. Moreover, it was found that there is no chemical interaction between the inorganic compounds and the organic molecules, and therefore no new compounds were formed. This corroborates the results previously reported by Benosman et al. (2012) and Zuccheratte et al. (2017).

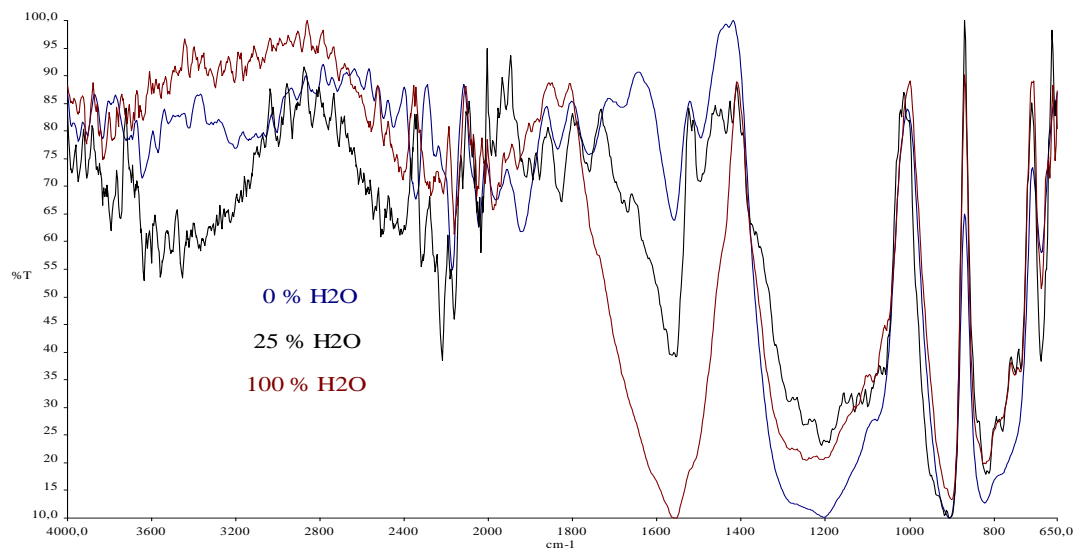

Fig 5. Superposition of the FTIR spectra of samples WPLA0, WPLA25 and WPLA100.

\subsection{Scanning Electron Microscopy (SEM) microstructural analysis}

The visualization of the microstructure of the PET-siliceous sand interface is illustrated in Figure 6 (SEM photo). The thermomechanical preparation of the WPLA composite aggregates allowed having a good adhesion and an excellent arrangement between the plastic PET waste and siliceous sand, as shown in Figure 6.

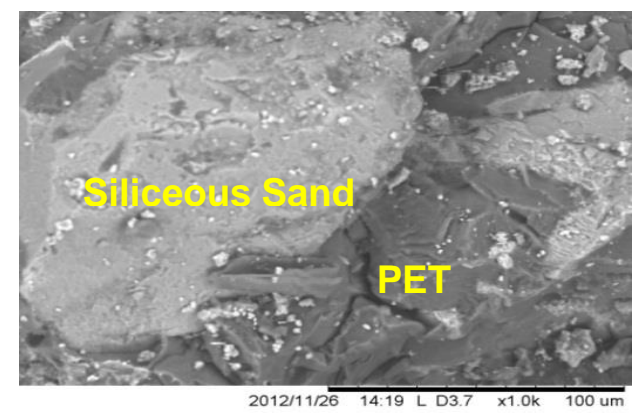

Fig 6. Microstructure of the PET- siliceous sand interface in the samples of the WPLA composite using SEM. 


\subsection{Differential scanning calorimetry (DSC)}

Some research (Kameche et al. 2009; NFT01-021, 1974; Platret and Deloye, 1994) has reported the identification, by thermal analysis techniques, such as DSC, ATD and ATG, of cement hydration products such as C-S-H gel, portlandite, ettringite, gypsum and calcite. Therefore, Silva et al. (2002) used the ATD analysis and showed the different changes resulting from the incorporation of Ethylene Vinyl Acetate (EVA) copolymer in composite materials. Similarly, Benosman et al. (2012) applied the ATD technique and reported the different alterations resulting from the addition of polyethylene terephthalate (PET).

The DSC curve (Figure 7 a) relative to siliceous sand presents two peaks; one is endothermic, around $570{ }^{\circ} \mathrm{C}$, and is due to the $\alpha-\beta$ phase transformation of quartz; the other one is exothermic and is found between $450{ }^{\circ} \mathrm{C}$ and $460{ }^{\circ} \mathrm{C}$. Polyethylene terephthalate (PET) is characterized by the three: vitreous, crystalline and melting phases corresponding to the three temperatures of $80^{\circ} \mathrm{C}, 130^{\circ} \mathrm{C}$ and $250^{\circ} \mathrm{C}$, respectively (Figure $7 \mathrm{~b}$ ).

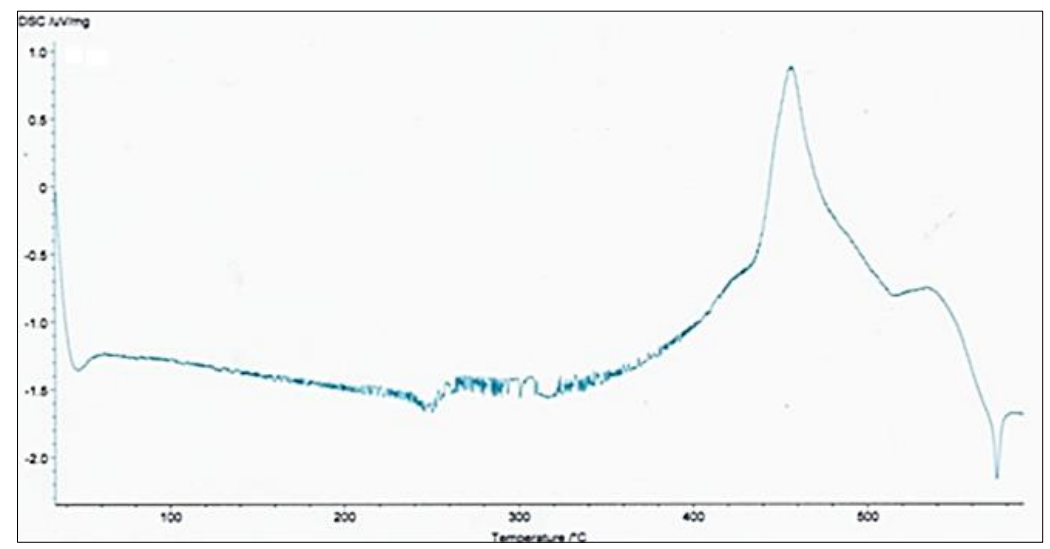

(a)

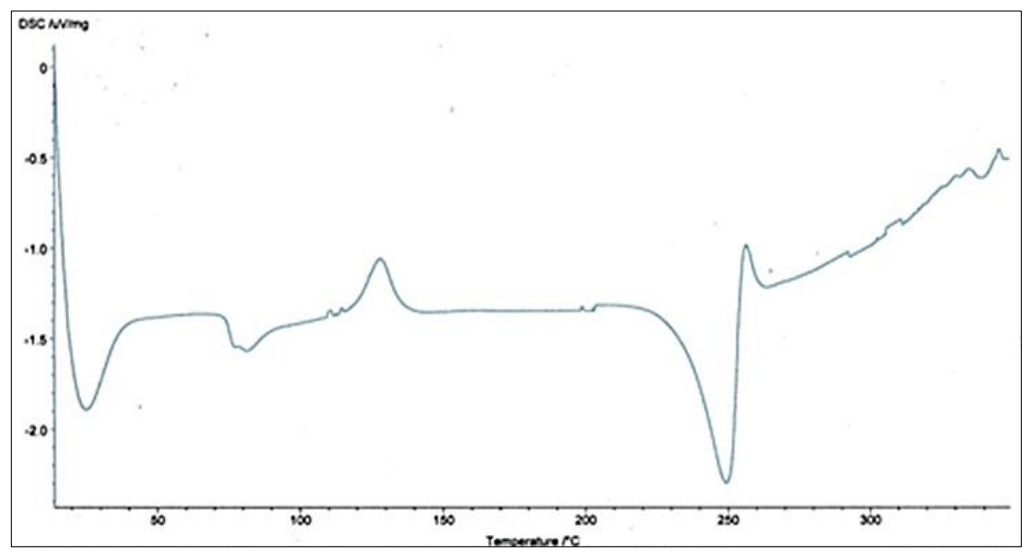

(b)

Fig 7. DSC curves, with a heating rate of $10 \mathrm{~K} / \mathrm{min}$, of: (a) siliceous sand, and (b) PET.

The characterization of the WPLA composite by the DSC technique (Figure 8a) indicates the presence of PET, which is confirmed by the presence of an endothermic peak corresponding to the melting temperature around $250{ }^{\circ} \mathrm{C}$ and an intense exothermic peak between $460{ }^{\circ} \mathrm{C}$ and $520^{\circ} \mathrm{C}$ (this peak is also observed in the case of siliceous sand). 


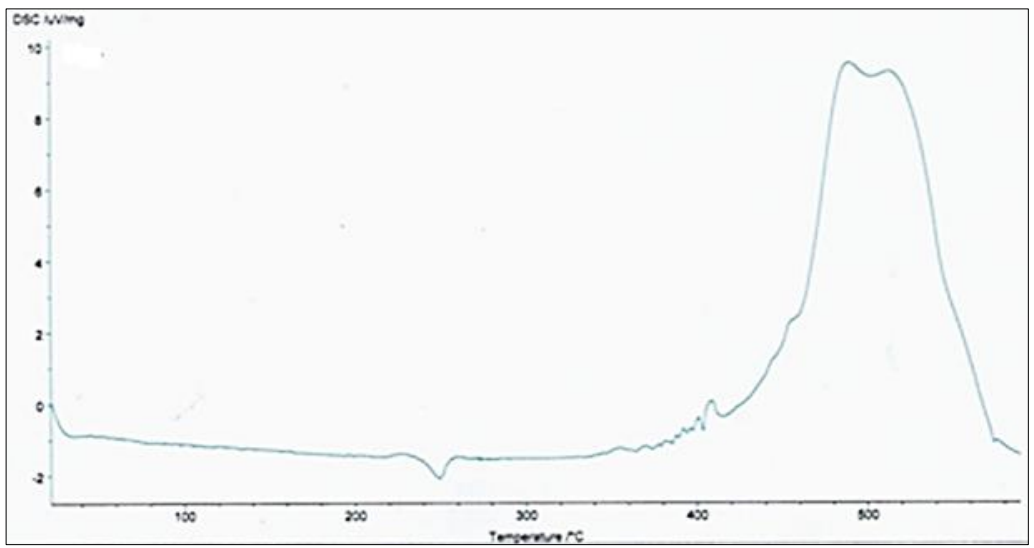

(a)

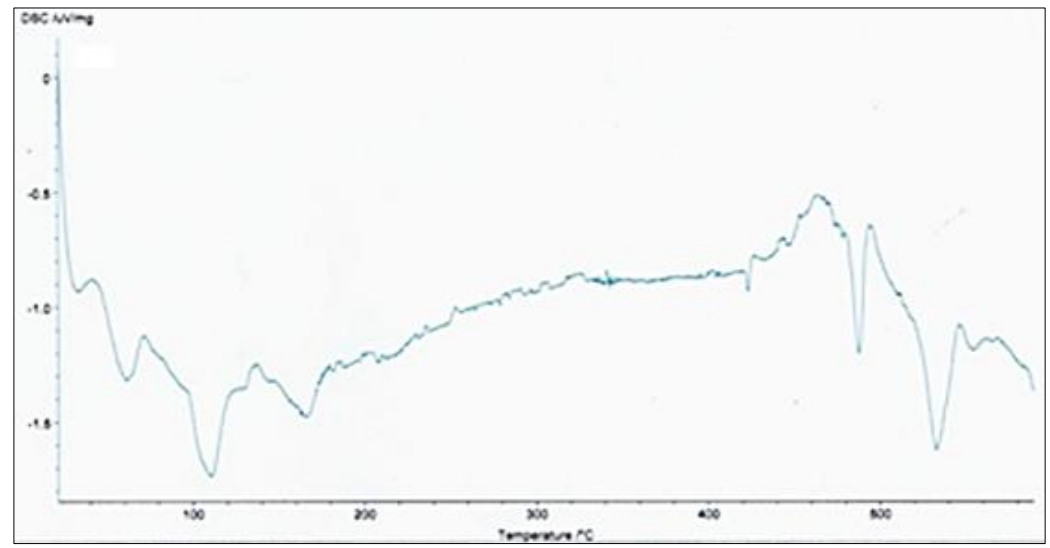

(b)

Fig 8. DSC curves, with a heating rate of $10 \mathrm{~K} / \mathrm{min}$, of: (a) WPLA composite aggregate, and (b) WPLA0 stored in fresh water.

The DSC curves, obtained for all tests, are typical for hydrated cement pastes (Figures $8 \mathrm{~b}$ and 9). Five major endothermic reactions occurred, during the sample heating, as follows:

- Between 30 and $105{ }^{\circ} \mathrm{C}$ : free water and some of the adsorbed water escaped from mortar. It was completely removed at $105^{\circ} \mathrm{C}$,

- Between 100 and $200{ }^{\circ} \mathrm{C}$ : various dehydration stages of $\mathrm{C}-\mathrm{S}-\mathrm{H}$ and ettringite were observed,

- At $140{ }^{\circ} \mathrm{C}$ : decomposition of gypsum $\mathrm{CaSO}_{4} \cdot 2 \mathrm{H}_{2} \mathrm{O}$,

- Between 175 and $190^{\circ} \mathrm{C}$ : hydration of calcium monocarboaluminate,

- Between 470 and $500{ }^{\circ} \mathrm{C}$ : dehydration of portlandite $\mathrm{Ca}(\mathrm{OH})_{2}$. 


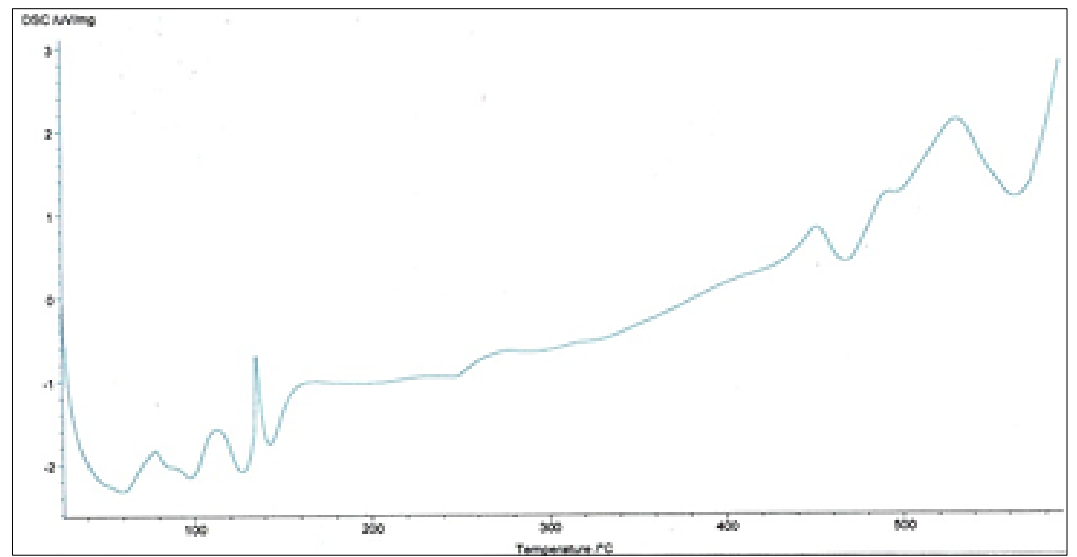

Fig 9. Differential Scanning Calorimetry (DSC) Thermal Analysis of WPLA50 immersed in water.

The incorporation of the WPLA (PET-siliceous sand) composite into polyphase materials affects the DSC curve, as this can be seen in Figure 9. Peaks are observed:

- Between 30 and $105^{\circ} \mathrm{C}$ : free water and some of the adsorbed water escaped from mortar. It was completely removed at $105^{\circ} \mathrm{C}$,

- Between 100 and $200{ }^{\circ} \mathrm{C}$ : various dehydration stages of C-S-H and ettringite were observed,

- An exothermic peak was found at $130{ }^{\circ} \mathrm{C}$; it characterizes the crystallization temperature $\mathrm{T}^{\circ} \mathrm{C}$ of PET,

- Around $140{ }^{\circ} \mathrm{C}$ : decomposition of gypsum $\mathrm{CaSO}_{4} \cdot 2 \mathrm{H}_{2} \mathrm{O}$, probably concealed by the peak of crystallization temperature $\mathrm{Tc}^{\circ}$ of PET,

- Decrease in the intensity of the endothermic peak for the dehydration of calcium hydroxide $\left(\sim 455^{\circ} \mathrm{C}\right)$,

- The melting temperature of PET was observed at $255^{\circ} \mathrm{C}$,

- Significant changes were noted on the DSC curve, for temperatures above $500{ }^{\circ} \mathrm{C}$ (an exothermic shoulder was detected between 510 and $520^{\circ} \mathrm{C}$ ). This is certainly due to the presence of the WPLA composite,

- An endothermic peak was found around $565^{\circ} \mathrm{C}$, surely resulting from the transformation of the structure from quartz $\alpha$ into quartz $\beta$, indicating the presence of siliceous sand.

These results confirm those previously reported by Benosman et al. (2016).

\section{Conclusions}

On the basis of the above, the following conclusions can be drawn:

- Analytical methods, such as FTIR, XRD, SEM and DSC, revealed that the composition of the materials studied remained qualitatively unchanged and that the chemical interactions between the mineral species and the WPLA aggregate or the composite itself did not lead to the formation of new compounds. As part of a first attempt to evaluate an unknown material, the FTIR spectrometry could provide a wealth of interesting information which was later confirmed by analytical means, better suited to the cases to be treated.

- From the thermogravimetric studies previously carried out, the results of which are illustrated by the DSC curves, it can be concluded that the addition of the PET-based WPLA composite aggregate has an impact on the hydration of cement. 
- The thermomechanical development of the WPLA composite aggregates enabled us to obtain a good adhesion and an excellent arrangement between the PET plastic waste and siliceous sand. A rough surface of the composite aggregate was obtained; it exhibited better adhesion and a larger contact area between the WPLA and the cementitious matrix (Gouasmi et al. 2015a). Thus, it can be said that the incorporation of PET lead to a densification of the cementitious matrix, and consequently a significant improvement in the durability of the material.

The use of composite aggregates containing PET waste and siliceous sand in building materials seems to be feasible given the interesting results obtained during the analysis of their properties. Positive results have been obtained by the author (Gouasmi et al. 2015a,b, 2016) concerning the use of this composite aggregate in building materials. This study is certainly a valuable contribution to the PET waste recycling program and the reduction of pollution in order to preserve the environment.

\section{Acknowledgments}

We would like to acknowledge the financial contribution within the framework of the Algerian project CNEPRU B00L01UN310120130068. The authors would also like to thank the HASNAOUI Group of Companies, TEKNACHEM Algeria and the late Ahmed TALEB. Furthermore, the authors would like to warmly thank Mr. M. Benabadji for the Proofreading and Linguistic Review of this paper.

\section{References}

Akçaözoğlu, S., Akçaözoğlu, K., \& Atiş, C.D. (2013). Thermal conductivity, compressive strength and ultrasonic wave velocity of cementitious composite containing waste PET lightweight aggregate (WPLA). Composites: Part B, 45, 721-726.

Alfahdawi, I.H., Osman, S.A., Hamid, R., \&. Al-Hadithi, A.I., (2016). Utilizing waste plastic polypropylene and polyethylene terephthalate as alternative aggregates to produce lightweight concrete: a review. Journal of Engineering Science and Technology, 11(8) 1165-1173.

Alqahtani, F.K., Ghataora, G., Khan, M.I., \& Dirar, S. (2017). Novel lightweight concrete containing manufactured plastic aggregate, Construction and Building Materials, 148, 386-397.

Alqahtani, F.K., Khan, M.I., \& Ghataora G. (2014). King Saud University, Synthetic aggregate for use in concrete. U.S. Patent 8, 921, 463. https://www.google.com/patents/US8921463

ASTM C109/C109M. (2011). Standard Test Method for Compressive Strength of Hydraulic Cement Mortars (Using 2-in. or [50-mm] Cube Specimens), ASTM, Philadelphia, United States.

ASTM C1437-01. (2001). Standard Test Method for Flow of Hydraulic Cement Mortar, ASTM, Philadelphia, United States.

ASTM C511-06. (2006). Standard Specification for Mixing Rooms, Moist Cabinets, Moist Rooms, and Water Storage Tanks Used in the Testing of Hydraulic Cements and Concretes, ASTM, Philadelphia, United States.

Benosman, A.S, Mouli, M., Taibi, H., Belbachir, M., Senhadji, Y., Behlouli, I., \& Houivet, D. (2012). Mineralogical study of Polymer-Mortar Composites with PET polymer by means of spectroscopic analyses. Materials Sciences and Applications, 3(3), 139-150.

Benosman, A.S., Taïbi, H., \& Mouli, M. (2016). Performances Mécaniques et Durabilité des Composites Mortier-PET, Recherche et Développement dans la Revalorisation et l'Application des Déchets du PET en Génie Civil. Maison d'édition : Editions universitaires européennes EUE.

Choi, YW., Moon, DJ., Chung, JS., \& Cho, SK. (2005). Effects of waste PET bottles aggregate on the properties of concrete. Cement and Concrete Research, 35, 776-781. 
Choi, YW., Moon, DJ., Kim, YJ., \& Lachemi, M. (2009). Characteristics of mortar and concrete containing fine aggregate manufactured from recycled waste polyethylene terephthalate bottles. Construction and Building Materials, 23, 2829-2835.

Fiches Techniques, G11. (2013). Les bétons : formulation, fabrication et mise en œuvre, ed, Collection technique CIMbéton, T.2, Chap.1. pp. 22-25.

Gouasmi, M.T., Benosman, A.S., Taibi, H., \& Belbachir, M., \& Senhadji Y. (2015b). Effect of a Composite Aggregate on the Durability of Mortars. Journal of Chemistry and Materials Research, 3, 26-31.

Gouasmi, M.T., Benosman, A.S., Taïbi, H., Belbachir, M., \& Senhadji Y. (2016). The physico-thermal properties of mortars made of composite aggregates "PET- siliceous sand". Journal of Materials and Environmental Science, 7(2), 409-415.

Gouasmi, M.T., Benosman, A.S., Taïbi, H., Belbachir, M., Senhadji, Y., \& Mouli, M. (2015a). Application des Agrégats Composites Légers dans les Mortiers : Cas d'une Chape Industrielle. In Proceedings of 2nd International Symposium CIMDD'2015, University M'hamed Bougara Boumerdes, Algeria (910 Nov.), (ISBN: 978-9931-9090-6-2).

Gouasmi, M.T., Benosman, A.S., Taïbi, H., Kazi Tani, N., \& Belbachir, M. (2017). Destructive and Nondestructive testing of an industrial screed mortar made with lightweight composite aggregates WPLA. International Journal of Engineering Research in Africa, 33, 140-158.

Gu, L., Ozbakkaloglu, T. (2016). Use of recycled plastics in concrete: A critical review. Waste Management, $51,19-42$.

Kameche, Z.A., Kazi Aoual, F., Semcha, A., \& Belhadji M. (2009). Effets des hautes températures sur le comportement du béton: application au revêtement des tunnels. In the Proceedings of the 1st International Conference SBEIDCO, 1, 199, ENPO Oran, Algeria, (12-14 Oct.). (ISSN 2170-0095).

NF EN 196-1. (2005). Methods of testing cement - Part 1: determination of strength, CEN.

Norme NF T01-021. (1974). Analyse thermique: Vocabulaire - Présentation des résultats, décembre.

Platret, G., \& Deloye, F.X. (1994). Thermogravimétrie et carbonatation des ciments et des bétons, Acte des Journées des Sciences de l'Ingénieur. 1, 273, Giens, France (4-7 Octobre).

Silva, D.A., Roman, H.R., \& Gleize, P.J.P. (2002). Evidences of chemical interaction between EVA and hydrating Portland cement. Cement and Concrete Research, 32, 9, 1383-1390.

Zuccheratte, A.C.V., Freire, C.B., \& Lameiras, F.S. (2017). Synthetic gravel for concrete obtained from sandy iron ore tailing and recycled polyethyltherephtalate. Construction and Building Materials, 151, 859-865. 